\title{
A Note on the Information Content of Corporate Dividend Policy
}

\section{Ayesha Khanum*}

\section{Introduction}

This note discusses the significance of the information content of dividends, which is reflected through the market price reactions to a firm's dividend decisions. Informational asymmetries are the main reason for signaling whereby firm managers are likely to have better information than external participants, implying that their financial decisions will tend to convey the firm's future prospects to the market. An efficient signaling equilibrium is that optimal combination of signaling costs and agency costs that minimizes any dissipative costs. An important consideration is the preference of the investor for dividend income versus capital gains due to the higher tax differential in the case of dividends.

There are two major types of asymmetric information: adverse selection and moral hazard. In adverse selection, the managers of a company have more information on hand relating to the firm's future prospects and current situation than outsiders or external investors. This may lead them to exploit their advantage at the cost of others. For example, they may choose to manage the amount of information released to investors, thus affecting the latter's decision to make a certain investment. This can affect investors' ability to make good investment decisions.

Signaling is one mechanism that can be used to resolve the problem of adverse selection. Another mechanism used to control this problem is financial reporting, which credibly converts inside information into public information. The other issue arising from asymmetric information is moral hazard, which is initiated by the separation of ownership and control in most medium and large businesses. Shareholders cannot necessarily observe the extent and quality of top managerial effort made directly on their behalf. Managers may, therefore, take advantage of this and compromise on the quality of their effort.

\footnotetext{
* The author is assistant editor of the Lahore Journal of Economics.
} 
Additionally, managers may blame any erosion of firm performance on factors beyond their control. In such cases, there are implications for investors. One effective solution to the problem of moral hazard is accounting net income, which can be incorporated into managerial compensation contracts, thus helping to motivate managers' performance. Net income can also help inform securities and managerial labor markets. Thus, if managers shirk their duties, they will have to endure a decline in income, reputation, and market value over a certain time period. The rest of this note summarizes some of the empirical findings on the relevance of dividends.

\section{Impact of Dividend Announcements on Share Prices}

Lang and Litzenberger (1989) analyze the impact of dividends on share prices. They test the implication that overinvestment problems are likely to be more obvious in firms experiencing decreasing investment opportunities and, therefore, higher prices will accompany a dividend increase announcement by such firms. They suggest that, in response to a dividend change, the market return is larger for firms that are likely to overinvest compared to those that are likely to maximize their value.

Howe, He, and Kao (1992) assess Lang and Litzenberger's (1989) propositions to determine if these findings hold for a larger set of infrequent cash expenditures, i.e., tender offer share repurchases and specially designated dividends (SDDs). They analyze the effect of one-time cash distributions or infrequent cash distributions to see if a market reaction to an extended set of transactions is explained by the free cash flow hypothesis. Their results suggest that firms may attempt to send a signal to the market when their shares are undervalued. Most such signals are made through repurchase announcements or SDDs.

Brous and Kini (1994) strongly support the signaling hypothesis in their explanation of the content of SDD announcements; the other two hypotheses-including the free cash flow hypothesis and wealth transfer effect-yield insignificant results. Their results also indicate significant and positive stock price reactions to SDD announcements and a positive relationship with the announcement period for abnormal stock returns. They conclude that information about future earnings is conveyed through SDD announcements.

Divecha and Morse (1983) establish two effects that could explain market reactions to dividend policy: the information effect and the tax 
effect. The information effect demonstrates that, other factors held constant, security returns realized on the announcement day are actually an outcome of dividend changes. To examine the tax effect, the study divides the sample into two portfolios with respect to the direction of the change in dividend payout ratio. The authors report that the investor's tax-paying preference forces them to react against higher dividends and favor a lower dividend instead.

Miller and Rock (1985) and Bhattacharya (1979) support the idea that the existence of asymmetric information can explain the signaling equilibrium, but their contributions-despite having a strong theoretical standing-do not illustrate in depth how dividends act as a strong source of information. Instead, they look at the properties of dividends that arise from signaling models. Both studies argue that, since individuals outside the firm have less information about its cash flows compared to the firm's managers, the latter have reason to clearly signal that information to investors.

Miller and Modigliani (1961) explain that dividends are irrelevant to predicting the firm's value. This idea is, however, only applicable when markets are perfectly efficient and prices reflect all the information available. From a more realistic viewpoint, when there are information asymmetries and corporate insiders tend to have more information than common investors, the information content of dividends (ICD) hypothesis ${ }^{1}$ applies whereby we conclude that stock price movements are a positive function of cash dividends. "Information content" here simply refers to the signal that a dividend announcement is provided to market participants, triggering them to revise their expectations of the stock's intrinsic value.

Further research in this context by Bhattacharya (1979) has developed a counterpart of the ICD hypothesis. This holds that dividends are a source of eliminating asymmetric information from the market and bear a cost for the firm; this can also be referred to as the "signal value."

Eades (1982) introduces the signal value into his analysis and presents two important relationships that help in further testing: one, that the signal value is a positive function of the company's true value and, two, that it has a negative relationship with the risk component of the company's value. Since the dividend yield is negatively related to the company's specific risk $(\beta)$, he applies a simple regression model to test

\footnotetext{
${ }^{1}$ Rise in stock price due to dividend signal.
} 
this relationship by taking the dividend yield as the dependant variable and $\beta$ as the independent variable. The results, by and large, do not accept the null hypothesis, i.e., that the dividend yield is independent of the risk coefficient and that there is a significant negative relationship. However, one weakness of this testing approach is that $\beta$ incompletely represents the firm's risk because it omits the residual component of risk, which also appears to be included as an independent variable. One important remark here is that a change in the level of dividends signals two important clues to the market: the firm's expected ending period value and its risk coefficient.

Some researchers have studied the impact of insider trading on ICD. Similar to dividend announcements, insider trading is an established signal to the market (John \& Lang, 1991). This activity (either buying or selling shares immediately prior to dividends) has a strong signaling effect and cannot be neglected. The resulting stock price response is related to factors such as the direction of dividend change, the direction of insider trading, and the nature of firm technology.

Asquith and Mullins (1983) find that the announcement effect of dividend initiations is positive. The signaling theory clarifies that excess returns are due to increased dividend announcements by firms (for details, see Laub, 1976). Stratifying the data with respect to insider trading activity reveals that the announcement day returns associated with insiders engaged in buying stocks are greater than the returns in which insiders are found selling stocks. Therefore, in the case of firms with net insiders selling, the stock price response is negative.

Other signaling predictions are that dividend increases accompanied by no unusual insider trading should cause no price change or that dividend increases accompanied by unusual insider selling should signal bad news and elicit a negative stock price reaction. Easterbrook (1984) criticizes the dividend signaling hypothesis on several grounds, asking what dividends actually signal, how they do so, and why they should be counted as better signals than other, apparently cheaper, methods such as audited reports. His argument is interesting as, on the surface, the message conveyed by dividends is often ambiguous. According to Easterbrook, this ambiguity is rooted in the modern corporate structure whereby managers assume the role of imperfect agents for outsider shareholders. This leads to dividend policies designed to minimize the sum of capital and agency costs. 
Previous empirical studies conducted to address ICD either through the use of event study methodologies or time-series regression (for example, Laub, 1976; Gonedes, 1978) have been criticized for their inability to identify accurately the information directly conveyed by dividends.

Garrett and Priestley (2000) analyze the dividend behavior of stocks, using a modified objective function of the dividend decision that is based on variations of actual dividends from permanent earnings or the target level and adjustment costs. They criticize Lintner's (1956) model and point out that it consistently penalizes the adjustment of dividends regardless of whether the adjustment brings the actual value nearer to the target. Their major finding is that dividends do convey information on unexpected changes in current permanent earnings and that both tests for signaling and the dividend's speed of adjustment to target dividends are sensitive to the model's specification.

Kao and Wu (1994) apply a new direct test to determine the relationship between unexpected dividends and changes in earnings. Their results show that a change in the level of dividends is reflected in (i) managers' permanent earnings expectations (future); (ii) unexpected changes in earnings prospects; and (iii) past, current, and future earnings. These results differ from studies such as Nakamura and Nakamura (1985) on account of the ability of dividends to reflect more than just current and one-period-lagged earnings information, thereby widening the spectrum of study. The results also suggest that dividends convey earnings prospects in the year of and the year following dividend initiation. This process tends to prevail for about two years following the dividend payment.

\section{Relevance of Announcement to Shareholder Wealth, Expected Cash Flows, Interest Rates, and Agency Costs}

The signaling theory rests on the idea that there are information asymmetries between corporate managers (insiders) and investors. Dividend announcements, therefore, serve as an essential tool for conveying unique information (to investors) about future firm value and prospects. Further, dividend initiation as an informative tool brings about positive reactions in the market and is responsible for changes in shareholders' wealth (total stockholders' equity). This shareholders' wealth can take either direction, i.e., it can be a negative wealth impact or a positive wealth impact, both of which are subject to situational variations. A negative wealth impact simply means that certain factors, when realized through a dividend initiation, can create negative trends in wealth. A 
positive wealth impact implies the presence of such factors that add value to the shareholder's wealth (ending wealth) and magnify returns.

Lewellen, Stanley, Lease, and Schlarbaum (1978) look at the "clientele" effect from a different viewpoint by using actual securities holding data from the equities marketplace for a large and diverse sample of individual shareholders. Their study focuses on the securities position, for which purpose they include each security's dividend yield. The dividend yield is calculated as the ratio of four times the preceding quarter's dividends to its 1970 closing market price. Since dividend income is subject to higher taxation vis-à-vis income from capital appreciation (gains), this signals a negative wealth effect, which automatically leads investors to avoid dividends and ultimately results in an outflow, implying that they are not better off. Moreover, if the firm plans to disburse a dividend financed by issuing new equity, this will also result in a negative wealth impact as the cost of new equity is always greater than the cost of old equity due to flotation costs - a huge percentage of the total issue.

Bernheim and Wantz (1995) study dividend signaling models under different tax regimes based on the alternative hypothesis that the information revealed by dividends does not necessarily take the form of dividend signaling. This view is formalized based on Lang and Litzenberger's (1989) study. Dividend signaling models generally imply that the per-dollar dividend share price response-or "bang-for-the-buck" (BFB) - increases with an increase in dividend taxation. ${ }^{2}$ As predicted by the models, the findings show that the response of the share price to a specific dividend signal will be greater if the dividend income is taxed. Additionally, there is a significant negative coefficient for the relative tax burden and change in dividend yield; these findings are in line with the signaling hypothesis predictions. The model used by Bernheim and Wantz shows an inverse relationship between the BFB and dividend tax rate.

Bernhardt, Douglas, and Robertson (2005) investigate whether a given dividend signal (unexpected change in the dividend level or yield) is related to a greater absolute excess return when income is unfavorably taxed under different tax regimes. They use a rank-ordering correlation test to look at the monotonic relationship between the $\mathrm{BFB}^{3}$ (Bernheim \& Wantz, 1995) and tax regimes. Their results support the agency theory, i.e., lower dividend announcement premiums are, in reality, related to higher tax rates.

${ }^{2}$ For details on the BFB, see Bernheim and Wantz (1995).

${ }^{3}$ Excess return linked with a specific dividend signal. 
Much of the argument in the literature on ex-dividend dates ${ }^{4}$ and announcement dates stems from the lack of sharp, convincing variations in tax rates. The results show that the hypothesis of independence between excess returns linked with a given change in dividend yield, level, or signal and the tax regime cannot be rejected. The marginal cost of dividends is negatively related to the ICD. The z-test shows that tax regimes are positively related to the BFB. As predicted by the signaling models, the excess return is more strongly related to the tax regime than the BFB. The reason for dividend distribution is not explained by the signaling concerns. Overall, the findings above run contrary to Bernheim and Wantz (1995).

In order to understand the problem of agency cost, it is important to consider Crockett and Friend's (1988) arguments that (i) stockholders agree to dividends because they want to avoid incurring agency costs, ${ }^{5}$ (ii) that dividends have a strong signaling force, (iii) that investors are riskaverse, and (iv) that transaction costs/liquidity risk are associated with the liquidation of stock. Agency cost refers to the fear that the firm's management is not basing its decisions entirely in favor of the owners. Shareholders are thus willing to pay a dividend-related tax cost to reduce the agency cost.

Crockett and Friend (1988) relate the realized (ex-poste) rate of the return to beta (risk coefficient) to the dividend yield, using a joint capital asset pricing model (CAPM). Their hypothesis is that investors are indifferent between after-tax dollar expected dividends and after-tax dollar expected capital gains. This leads to the conclusion that the required rate of return is a positive linear function of the dividend yield. However, the CAPM-based results create confusion when concluding that corporations choose to incur a high cost of equity by paying more dividends than are actually required, especially given the option of utilizing those funds elsewhere, e.g., by repurchasing stock.

The agency signaling scenario incorporates both the agency problem (as explained earlier) and signaling models. In many situations, the cost of signaling is considered part of the agency cost in the form of an extension or increment-an outcome of the firm's capital structure decision. Agency studies tend to associate the structure of claims with corporate assets and related conflicting issues and the incomplete exposure

\footnotetext{
${ }^{4}$ The date after or on which a security is traded without a past declared distribution or dividend.

${ }^{5}$ When a firm acquires debt, an agency cost arises because of the conflict between bondholders and stockholders. Stockholders are tempted to follow selfish strategies, imposing an agency cost on the firm, in turn lowering the firm's market value.
} 
of outsiders with investment/financing actions adopted inside the firm, affecting the worth of their claims.

Sembenelli's (1993) model of financial signaling holds that outsiders act rationally when drawing inferences about insider policies regarding capital structure. The signaling effect in itself is a positive indicator and, under equilibrium conditions, the existence of the agency problem may also be seen as a favorable revaluation of the firm by the market. Most empirical findings (see John, 1987) also show that, in cases where levels of risky debt have risen-causing agency costs to rise-the signaling effect tends to smoothen leverage and bring about favorable revaluation responses by the market.

\section{Dividend Policy and Market Signals}

Lintner's (1956) 6 model of corporate dividend policy has a comparatively direct effect on longer-term growth trends and recurring fluctuations in the economy. His results show that the parameters used are not biased and the study's major finding is that, over long periods, investment costs remain consistent and have a high correlation with sales volume, current profits, and internal funds. An acceptance of these relationships is built into corporations' dividend policies in a way that they are easily able to pay the dividends implied by these policies over a longer period. Moreover, the statistics indicate that the basic model includes the determinants of the main corporate dividend decisions and shows that the parameters are plausibly consistent over time.

Fama and Babiak (1968) analyze the determinants of individual firms' dividend policies and find that a measure of current profits and lagged dividends help explain dividend changes. The most appropriate measure of profits is net income rather than the cash flow model. For the Monte Carlo experiment, the results show that Lintner's model performs well and that serial dependence in disturbances is not a serious problem. Both Lintner (1956) and Fama and Babiak (1968) thus find that dividend policy is a major factor resulting in a positive wealth impact: it provides investors with quality information that reflects managers' perceptions of firm performance and their forecast of future trends. This addition to investors' knowledge is realized in the face of a monetary advantage that increases net worth.

\footnotetext{
${ }^{6}$ The model states that dividend policy has two parameters: (i) the target payout ratio and (ii) the speed at which current dividends adjust to the target.
} 
With reference to the assumptions made by Asquith and Mullins (1983), investors can have expectations about the future in two directions: (i) either no expectation of future dividends at all, implying that any change in dividends will be unexpected, or (ii) some sort of expectation of future cash flows.

Yoon and Starks (1995) argue that there is an asymmetry between dividend decreases and dividend increases at the individual firm level. They investigate the association between the firm's investment opportunity set and dividend changes and the relationship between the overinvestment or cash flow signaling hypothesis and the wealth effects accruing from dividend change announcements. They note that Lang and Litzenberger's (1989) finding alone is not perfect proof against the free cash flow hypothesis and suggest a more suitable test for determining the sources of the wealth effects implied by the two competing hypotheses.

Yoon and Starks (1995) find that, after the dividend changes and in spite of their investment opportunities over a three-year period, firms notably increased (decreased) their capital expenditures after a dividend increase (decrease). The announcement of a dividend decrease or increase in terms of changes in cash flow expectations is the major basis for analysts to modify their current earnings forecast in line with the signaling hypothesis. The long-term earnings growth forecast is lowered following a decrease announcement but not after a dividend increase announcement. This result explains why a decrease in dividends causes a greater stock price reaction than an increase in dividends announcement. Yoon and Starks thus favor cash flow signaling over free cash flow signaling.

Bar-Yosef and Huffman's (1986) reward-penalty managerial incentive scheme helps explain corporate dividend policy in terms of an incentive for the manager to signal accurately. An ideal scheme would have two traits: (i) it would signal the knowledge as soon as it became available, so the manager must be rewarded according to the value of the firm based on how quickly the information becomes available; and (ii) it would ensure accuracy otherwise the scheme would penalize the manager for providing overestimated or false information.

For the scheme to be implemented efficiently, the manager must be prevented from taking part in any trading activity pertaining to his own firm's stock so that he cannot exploit the knowledge he has beforehand. Additionally, his post-announcement trading activity must be governed by disclosure rules so that he cannot raise his compensation (incentive) by 
passing on an incorrect expectation of cash flow. As a result, the size of the declared dividend will be positively proportional to the expected cash flow, which is natural as the higher the potential cash flow, the more likely the firm will be to distribute it among its owners.

As far as the relationship between dividend policy and the payout ratio and interest rates is concerned, the literature indicates that interest rates have a less clear-cut effect on the payout ratio; theoretically, this can be identified as an indirect impact. However, researchers such as Brittain (1966) show that dividend payments are a decreasing function of interest rates. If the economy is expected to be weak and earnings prospects are uncertain - when the growth of a sector is doubtful-then this leads to a decline in the dividend payout ratio since managers may not expect sufficient earnings to support a dividend decision.

It is commonly held that dividends are a useful signaling tool for a firm's management to transmit information to investors in times of information asymmetries. However, Lintner (1956), Fama and Babiak (1968), and Laub (1976) present models in which dividends resolve any sort of information asymmetries present and are weakened by the fact that firms stabilize their payout ratios " $\mathrm{d}$ " if the earnings have perfect serial correlation. Therefore, dividends may not always be a very good predictor of earnings (Penman, 1983). Penman (1983) also finds that less information is conveyed by dividend changes after controlling for the management's future earnings forecast.

While some studies argue that dividends are a complete transmitter of information (which is obviously an overestimation), others hold that they are irrelevant to the firm's prospects (again, a superficial notion). A rational way to handle this is to consider dividends as being responsible for passing on only "some" information rather than its complete content.

The rational approach says that shareholders will prefer stocks and will lower the payout to avoid heavy personal taxation on dividend income. Modigliani (1982) points out that all possible estimates of the effective capital gains tax rate prove to be much lower than the effective personal tax rate imposed on dividend income. So, ideally, the corporation will not pay dividends for the welfare of its owners. Historical trends and even recent market studies, however, do not show that firms pursue such (anti-dividend paying) policies. 


\section{Conclusion}

The signaling effect of dividends has been debated for over three decades. ICD refers to the message that dividends transmit to market participants. It is common knowledge that corporate insiders possess information that is not accessible to investors; dividend announcements are, therefore, one way of transmitting this knowledge to the public. Normal price reactions to dividend announcements are positive, which means that an increase in dividends will be met by an increase in stock prices, thereby yielding positive announcement day returns.

Another phenomenon that also constitutes a signal is the insider trading prevalent around dividend announcements. This provides the market with a signal and the resulting security returns reflect insider activity. Insider buying indicates a positive signal while insider selling sends negative signals to the market. Efficient signaling is that optimal mix of both signals (insider trading and announcement of dividends) that incurs the minimum signaling cost. To test the accuracy of ICD, contemporary tests involve a rational signaling equilibrium. These provide useful and statistically significant results, showing that dividends signal future earnings prospects and apply to more than one-period time-lagged earnings information.

In reality, we do not really know if shareholders' wealth is affected by dividend policy, but the empirical evidence does seem to suggest that it is important or is perceived to be so. Dividend decisions should, therefore, be taken carefully, given the limitations of real world capital markets. Whether a dividend decision is correct will depend on the extent to which an individual shareholder is affected by various market imperfections. Market imperfections affect individual shareholders in many contradictory ways with respect to dividends, making it difficult to agree on a single dividend policy. The only way for a company to escape this quandary is to maintain a consistent dividend policy that allows individual shareholders to assess its desirability with respect to their personal conditions. 


\section{References}

Asquith, P., \& Mullins, D. W., Jr. (1983). The impact of initiating dividend payments on shareholders' wealth. Journal of Business, 56, 77-96.

Bar-Yosef, S., \& Huffman, L. (1986). The information content of dividends: A signaling approach. Journal of Financial and Quantitative Analysis, 21, 47-58.

Bernhardt, D., Douglas, A., \& Robertson, F. (2005). Testing dividend signaling models. Journal of Empirical Finance, 12, 77-98.

Bernheim, B. D., \& Wantz, A. (1995). A tax-based test of the dividend signaling hypothesis. American Economic Review, 85(3), 532-551.

Bhattacharya, S. (1979). Imperfect information, dividend policy, and "the bird in the hand" fallacy. Bell Journal of Economics, 10, 259-270.

Brittain, J. A. (1966). Corporate dividend policy. Washington, DC: Brookings Institution.

Brous, P. A., \& Kini, O. (1994). The valuation effects of equity issues and the level of institutional ownership: Evidence from analysts' earnings forecasts. Financial Management, 23, 33-46.

Crockett, J., \& Friend, I. (1988). Dividend policy in perspective: Can theory explain behavior? Review of Economics and Statistics, 70(4), 603-613.

Divecha, A., \& Morse, D. (1983). Market responses to increases and changes in payout ratios. Journal of Financial and Quantitative Analysis, 18(2), 163-173.

Eades, M. K. (1982). Empirical evidence on dividends as a signal of firm value. Journal of Financial and Quantitative Analysis, 17(4), 471-500.

Easterbrook, F. H. (1984). Two agency-cost explanations of dividends. American Economic Review, 74(4), 650-659.

Fama, E. F., \& Babiak, H. (1968). Dividend policy: An empirical analysis. Journal of the American Statistical Association, 63(324), 1132-1161. 
Garrett, I., \& Priestley, R. (2000). Dividend behavior and dividend signaling. Journal of Financial and Quantitative Analysis, 35(2), 173189.

Gonedes, N. J. (1978). Corporate signaling, external accounting, and capital market equilibrium: Evidence on dividends, income and extraordinary items. Journal of Accounting Research, 16(1), 26-79.

Howe, K. M., He, J., \& Kao, G. W. (1992). One-time cash flow announcements and free cash-flow theory: Share repurchases and special dividends. Journal of Finance, 47(5), 1963-1975.

John, K. (1987). Risk-shifting incentives and signaling through corporate capital structure. Journal of Finance, 42(3), 623-641.

John, K., \& Lang, L. H. P. (1991). Insider trading around dividend announcements: Theory and evidence. Journal of Finance, 46(4), 1361-1389.

Kao, C., \& Wu, C. (1994). Rational expectations, information signaling and dividend adjustment to permanent earnings. Review of Economics and Statistics, 76(3), 490-502.

Lang, L. H. P., \& Litzenberger, R. H. (1989). Dividend announcements: Cash-flow signaling vs. free cash-flow hypothesis. Journal of Financial Economics, 24, 181-191.

Laub, M. P. (1976). On the informational content of dividends. Journal of Business, 49(1), 73-80.

Lewellen, W. G., Stanley, K. L., Lease, R. C., \& Schlarbaum, G. G. (1978). Some direct evidence on the dividend clientele phenomenon. Journal of Finance, 33(5), 1385-1399.

Lintner, J. (1956). Distribution of incomes of corporations among dividends, retained earnings, and taxes. American Economic Review, 46(2), 97-113.

Miller, M. H., \& Modigliani, F. (1961). Dividend policy, growth and the valuation of shares. Journal of Business, 34(4), 411-433.

Miller, M. H., \& Rock, K. (1985). Dividend policy under asymmetric information. Journal of Finance, 40(4), 1031-1051. 
Modigliani, F. (1982). Debt, dividend policy, taxes, inflation and market valuation. Journal of Finance, 37(2), 255-273.

Nakamura, A., \& Nakamura, M. (1985). Rational expectations and the firm's dividend behavior. Review of Economics and Statistics, 67(4), 606-615.

Penman, S. H. (1983). The predictive content of earnings forecasts and dividends. Journal of Finance, 38, 1181-1199.

Sembenelli, A. (1993). Signaling, financial hierarchy and agency theory as explanations for dividend behavior: Evidence from Italian firm data. Managerial and Decision Economics, 14(1), 37-45.

Yoon P. S., \& Starks, L. T. (1995). Signaling, investment opportunities and dividend announcements. Review of Financial Studies, 8(4), 995-1018. 